\title{
Construction Culture between Tradition and Modernity: Three Works by Âlvaro Siza
}

\author{
T. C. Ferreira \\ CEAU, Faculty of Architecture of the University of Porto
}

E. Fernandes

Lab2PT, School of Architecture of the University of Minho

F. Barbosa

Faculty of Architecture of the University of Porto

ABSTRACT: Between 1958 and 1966, Álvaro Siza designed three remarkable works in Leça da Palmeira: the Boa Nova Tea House (1958-63), the Swimming Pool at Quinta da Conceição (1958-66) and the Ocean Swimming Pool (1959-66; building completed in 1973). Even though these buildings were designed within a short space of time and were built in the same area, they reflect the evolution of the construction culture in Portugal during the 1950s and 1960s, which evolved from a predominant recourse to traditional technologies using pre-industrial materials (often taking the form of a hybrid combination with modern solutions) towards the gradual affirmation of modern construction features made possible by the advances in the construction industry (mainly reinforced concrete).

\section{INTRODUCTION}

Between 1958 and 1966, Álvaro Siza Vieira designed three important works in Leça da Palmeira, near Porto, in the north of Portugal: the Boa Nova Tea House (1958-63), the Swimming Pool at Quinta da Conceição (1958-66) and the Ocean Swimming Pool (1959-66). Although these projects were built in the same area and were designed almost simultaneously, their construction features are quite different: in Quinta da Conceição and in the Tea House, Siza used a mixture of traditional and modern materials (stone walls, pitched concrete slabs covered with tiled roofs), attempting to combine vernacular constructive elements with the use of modern technologies; in the Ocean Swimming Pool, however, Siza adopted an abstract neoplastic language and made a concerted use of modern technology (walls in reinforced exposed concrete).

This shift can be explained by the evolution of the construction culture and processes taking place in Portugal during the 1960s (in keeping with the evolution of the international debate), with Siza's work gradually amounting to a reaction to the formalist and regionalist trends arising from the 'Survey on Popular Architecture in Portugal' (1955-61).

This paper will present a comparative analysis of the construction features of the three works, with greater detail being provided in the Ocean Swimming Pool. Hence, the roles of the different actors involved in the building process (architects, engineers, contractors) are examined, as well as the materials and building technologies used, viewed in relation to the construction culture of this period, between tradition and modernity.

The methodology of this paper is based on oral sources (interviews to building actors), as well as the analysis and interpretation of documentation obtained from several public or private archives, such as drawings, administrative documents, manuals, notes, photographs, budget estimates, site calendars and academic works, among others.

The large amount of sources available allowed for a more detailed analysis in the case of the Ocean Swimming Pool, namely in relation to: i) the planning of the building site (staff, office and facilities for workers, chronogram), ii) the transport and manufacture of materials (crane, carpentry of the formwork, steel reinforcement building site, concrete mixer) and iii) the construction processes: demolitions, excavations made in the earth, sand and rock; hydraulic masonry foundations; landfills; reinforced concrete walls and roof slabs; loose stone drainage on the back of the retaining walls; waterproofing screens in the roofs; cyclopean concrete in the external pavements; flooring with concrete slabs; water supply devices, sanitary installations and infrastructures. 


\section{THE PORTUGUESE CONTEXT: BETWEEN TRADITION AND MODERNITY}

Between 1933 and 1974, Portugal was governed by the Estado Novo ('New State'), the dictatorial regime of António Salazar, which sought to impose a romantic vision of vernacular values on Portuguese architecture, combined with an imperial monumentality influenced by Nazi Germany and Fascist Italy (Fernandes \& Pereira 2019).

However, with the gradual affirmation of a new generation of building actors with international influences, the pressure from the State decreased, and the imposition of official languages was restricted to certain types of public buildings (such as courthouses); in private buildings, the modern style and construction solutions (directly influenced by Le Corbusier) dominated everyday production (Fernandes 2016).

The year of 1955 marked the beginning of the fieldwork for the Surveys on Portuguese Vernacular Architecture, a State-funded programme promoted by the Union of Portuguese Architects. If this was a final attempt by Salazar to create a 'Portuguese style' (as an alternative to modernism) in the work of architects, it failed: the Surveys proved that there was not just one single construction culture that was recognisable throughout the country (on the contrary, there were several regional variations) and demonstrated the compatibility between the vernacular legacy, modern values and construction features.

Hence, between 1955 and 1961 (during the survey on Popular Architecture in Portugal), a new Portuguese Architecture was born, in which traditional technologies (stone walls, timberwork, pitched roofs covered with ceramic tiles) were progressively combined with modern features such as reinforced concrete structures: the Municipal Market of Vila da Feira (1954-59), the Ofír House (1957-58), the Tennis Pavilion of Quinta da Conceição (1956-59) and the Cedro Elementary School (1957-61), all designed by Távora, and the Swimming Pool of Quinta da Conceição (1958-66) and the Boa Nova Tea House (195863), both initiated in Távora's office and later developed by Siza alone.

The popularity of the book Popular Architecture in Portugal (Amaral et al. 1961), created a regionalist trend in Portugal, as the reinterpretation of vernacular forms and constructive characters proved to be in tune with the modernist principles of functionality and the honest use of materials. However, during the 1960s, it became clear that this vernacular influence was crystallising "a reality that was, in fact, rapidly disappearing and could not express the contemporary times" (Fernandes 2016: 403-4).

This context explains the construction shift that can be detected when comparing the works by Siza that are presented in this paper: in other words, contrasting the Swimming Pool of Quinta da Conceição and the Boa Nova Tea House with the Ocean Swimming Pool of Leça da Palmeira.

\section{THREE WORKS BY ALVARO SIZA}

These three works were part of a plan for the promotion of tourism in the village of Leça da Palmeira, envisaged by the Mayor Fernando Pinto de Oliveira (1911-1975), and were built between 1958 and 1973, at an early stage in Siza's career.

\subsection{Boa Nova Restaurant and Tea House (1958-63)}

In Boa Nova, there is a carefully established dialogue between the Tea House, the pre-existing rocks and the nearby chapel; furthermore, the exterior and interior promenades have a constant correlation with the sea view (Ferreira \& Fernandes 2021, in press).

Initially designed at the studio of Fernando Távora for presentation in a public contest (won in 1956), the subsequent commission and its corresponding authorship were later entrusted by the master to Álvaro Siza (a collaborator in his office between 1955 and 1958).

The engineer for this project was Aires Pereira and the contractor was Soares da Costa, SA, a firm dedicated to the execution of high-quality workmanship, which, during the 1960s, expanded its activity in the Portuguese territory and, in 1980s, began its international expansion. At the end of the twentieth century, it was one of the largest contractors in the country.

Following the lessons that he had learned from Távora, Siza proposed the use of a mixture of traditional construction culture (timber joinery and ceilings, stone walls and ceramic tiles) and modern construction technology (pitched concrete slabs, reinforced concrete walls and pillars).

The building has sloping pitched roofs of brick slabs with a main structure of reinforced concrete beams, supporting a covering of Roman roof tiles, laid with a mortar made from cement, sand and water repellent. To fix the tiles in place, concrete slats were added to the slabs, with small openings to prevent water from accumulating in the event of rainwater infiltration. The roof's gutters and flashings are made of copper.

While the entrance floor is supported by a reinforced concrete slab, all of the ground floor is laid upon waterproofed concrete walls and foundations.

The reinforced concrete exterior walls and the basement are directly supported by the rocks or by cyclopean concrete walls.

On the other hand, the inner walls in perpend stone of $28 \mathrm{~cm}$ or brick of $15 \mathrm{~cm}$ are directly supported by a reinforced concrete foundation, while the rest of the 
building, also made of brick $(8,5$ and $3 \mathrm{~cm})$, is laid directly on the floor screed. In the western façade, the reinforced concrete pillars have a foundation made of the same material.

Apart from the building's foundations and pillars, all of the walls are plastered and painted white.

Most of the wooden elements are built in afzelia wood, used in the ceilings, in the interior flooring and in all the frames, including a set of sliding windows.

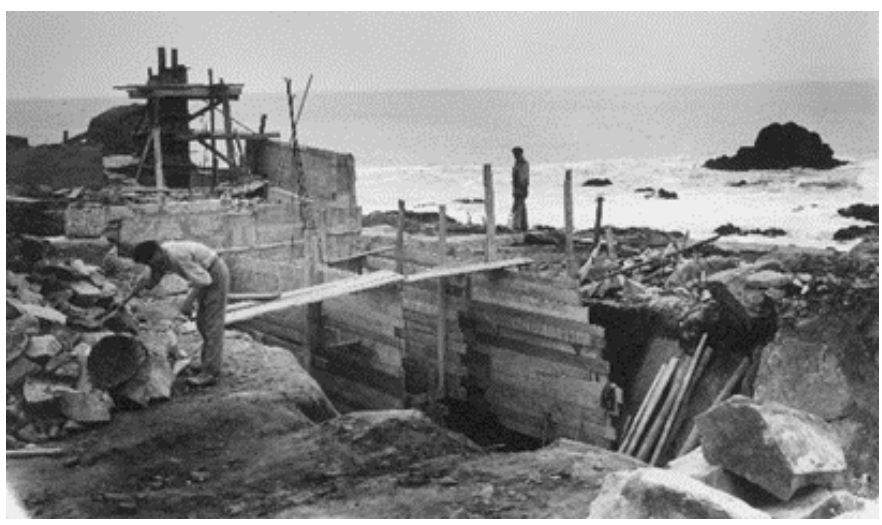

Figure 1 - Boa Nova Tea House and Restaurant, concrete foundations, 1959. (Câmara Municipal de Matosinhos)

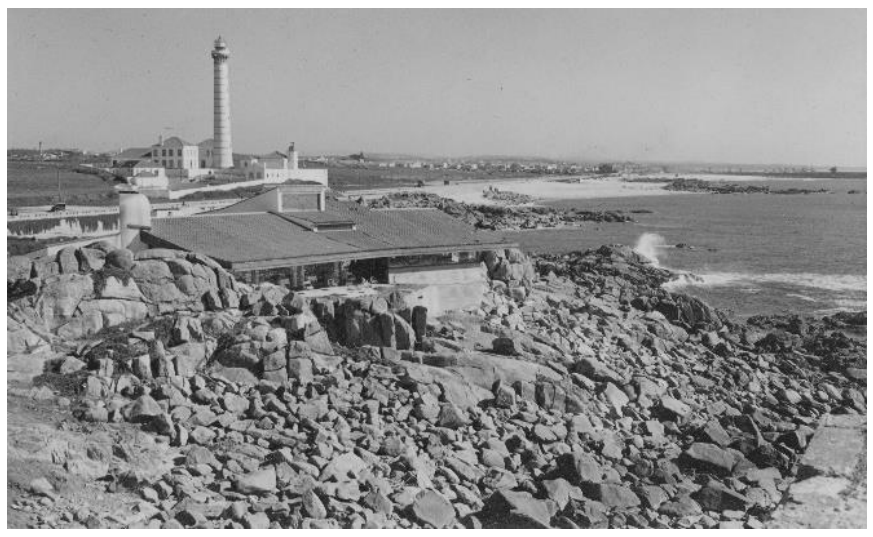

Figure 2 - Boa Nova Tea House and Restaurant, 1963 (Câmara Municipal de Matosinhos)

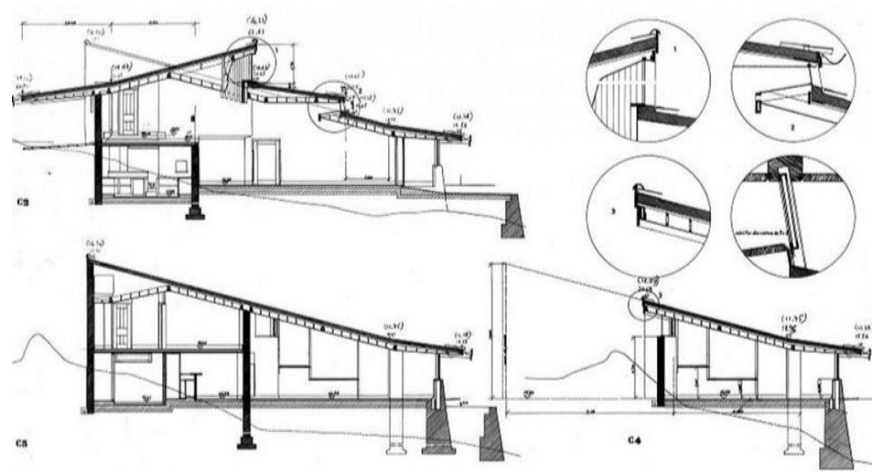

Figure 3 - Boa Nova Tea House and Restaurant, A. Siza, cross sections and details, 1959. (Câmara Municipal de Matosinhos)

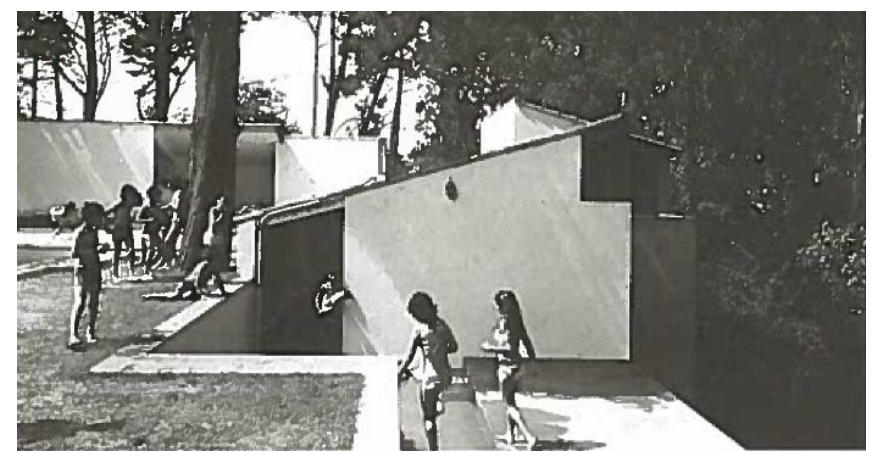

Figure 4 - Quinta da Conceição Swimming Pool, changing rooms 1965. (Trigueiros, L. 1997, p.43.)

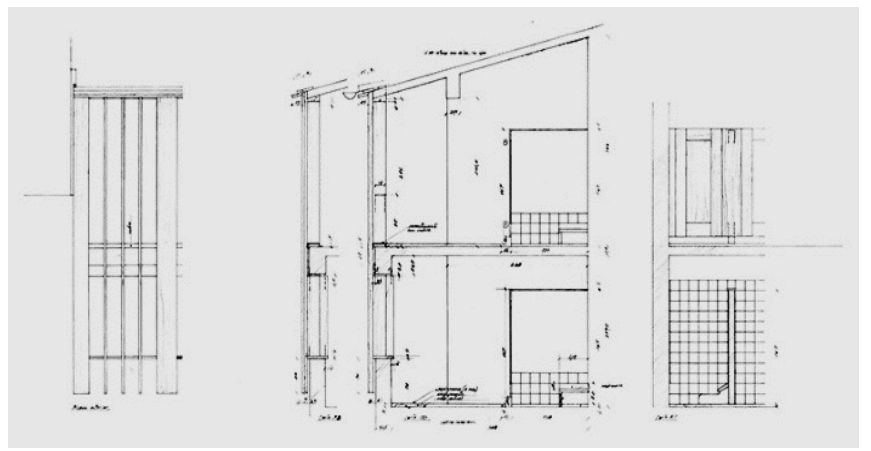

Figure 5 - Quinta da Conceição Swimming Pool, A. Siza, cross sections 1961. (Arquivo da Fundação Serralves)

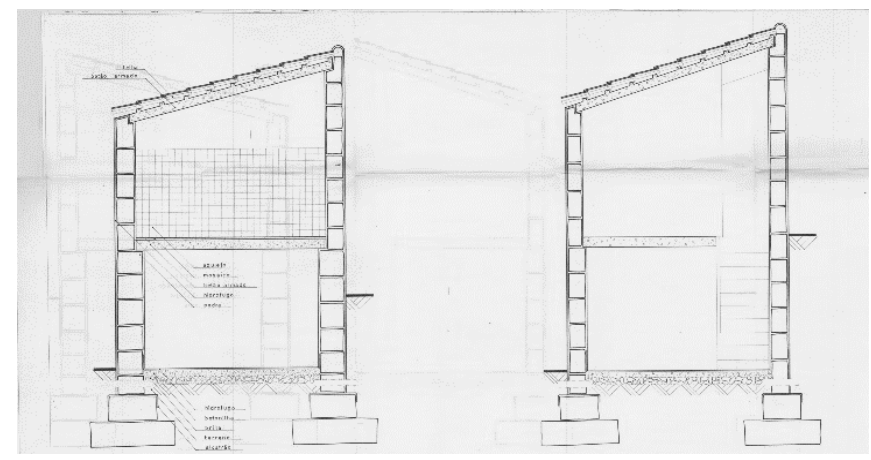

Figure 6 - Cross section of the Changing Rooms, Student Works 1991/1992 (Centro de Documentação da FAUP)

\subsection{Quinta da Conceição Swimming Pool (1958-66)}

The Swimming is implanted in a uphill path that passes through Quinta da Conceição, a public park designed by Távora (1956-60) in the grounds of an old convent (of which there were almost no traces).

For this construction, the engineer was Asdrúbal Teixeira Varejão and the contractor was a local firm Domingos Soares Lopes.

In this project, Siza once again used a combination of traditional construction culture (masonry walls, timber and ceramic tiles) and modern tectonics (reinforced concrete slabs and external walls).

The retaining walls and foundations of the buildings that house the bar and changing rooms are made with perpend stone. The walls are also sealed with granite masonry and the pool's walls are made of masonry with a concrete filling. The retaining walls of 
the southern area and of the technical areas on the lower floor are, however, built in cyclopean concrete. All the slabs are made of reinforced concrete with the exception of the ground floor of the bar and changing rooms. The roof slabs are covered with Roman tiles. The eaves and joinery are made of iroko wood.

Apart from the areas covered with turf and trees, all of the outside flooring was made of cement screed, while the concrete slabs are covered with plastic paint in the changing rooms and bathrooms, and ceramic tiles in the bar.

Built over the pre-existing water tank, the bottom of the swimming pool is made of concrete slabs, while the walls are made of masonry filled with concrete. All the joints were filled with hot plastic, while the walls were covered with mortar and painted.

\subsection{Ocean Swimming Pool (1959-73)}

In 1960, Siza began to design a second pool on the seafront of Leça da Palmeira, near the Tea House. The design of the $20 \times 33$-metre tank was commissioned from Bernardo Ferrão (Fernando Távora's brother) by Matosinhos Municipal Council. However, given the delicate nature of the landscape, he recommended Álvaro Siza to design the pool and the buildings.

The project has undergone several revisions over time; it opened to the public in 1965, but the building we find there today was only completed in 1970-73 when the $45^{\circ}$ wall was built, protecting the bar from the north wind (Ganshirt 2004). Siza proposed that the building should be anchored "like a boat, to the marginal wall", relating the gentle slope of the roofs to the three parallel lines visible at the site (Siza, A. 1980: 23-4).

Here, just as in the Quinta da Conceição Pool and in the Tea House, the architecture can only be fully appreciated from the promenade, where the building appeals to all human senses. However, in the Ocean Pool, such an effect is achieved through the different constructive options that were taken: the exposed concrete walls are shown in their rough natural state, still displaying the marks of the formwork. Despite the little use of cement and their limited reinforcement, these walls have gained a great binding over time and present a grey tone that is in perfect harmony with the pre-existing rocks and sand.

The gently sloping copper covering of the changing rooms displays a modern approach to an ancient system: it is supported by beams made of riga wood (recycled from demolished constructions), darkened by the burnt oil used in its treatment. The height of these roofs allows the creation of transversal natural ventilation between the roof and the walls. Also, all of the changing rooms' partition walls and most of the doors are also made of wood, which are either suspended on the roof or raised from the floor to allow easy washing of the pavement.

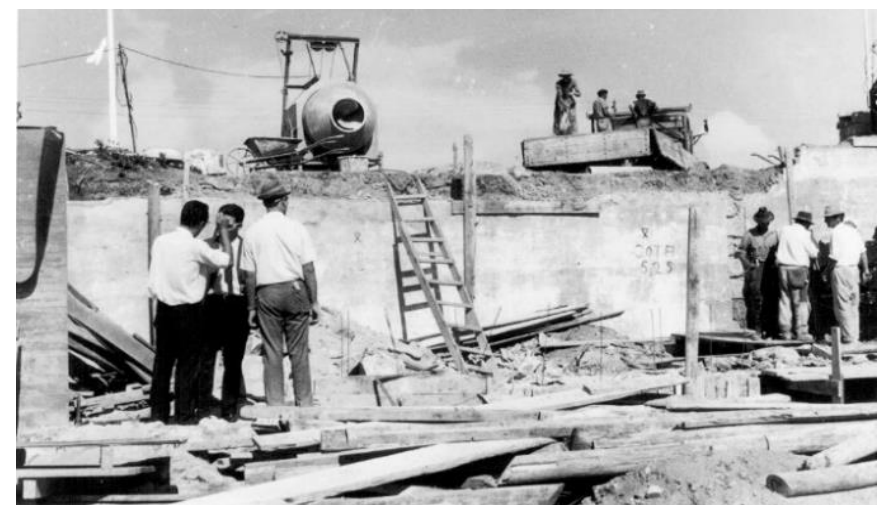

Figure 7 - Ocean Swimming Pool, construction of the southern area (Mota, 1872; Centro de Documentação da FAUP)

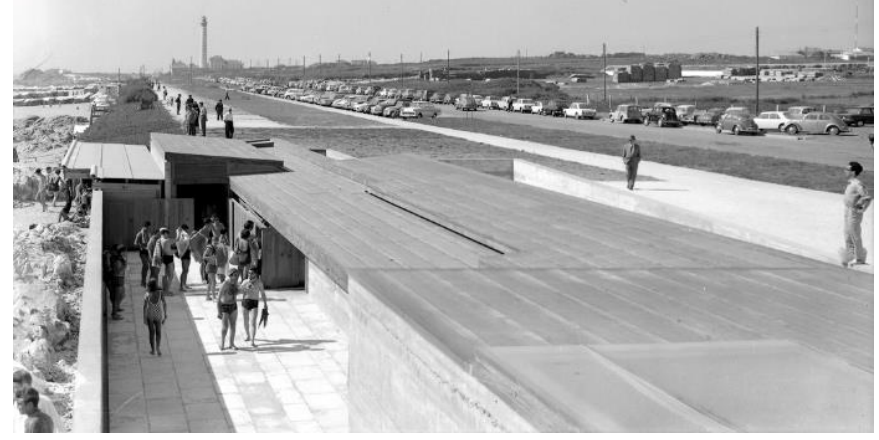

Figure 8 - Ocean Swimming Pool, building housing the changing rooms 1965. (Arquivo Câmara Municipal de Matosinhos)

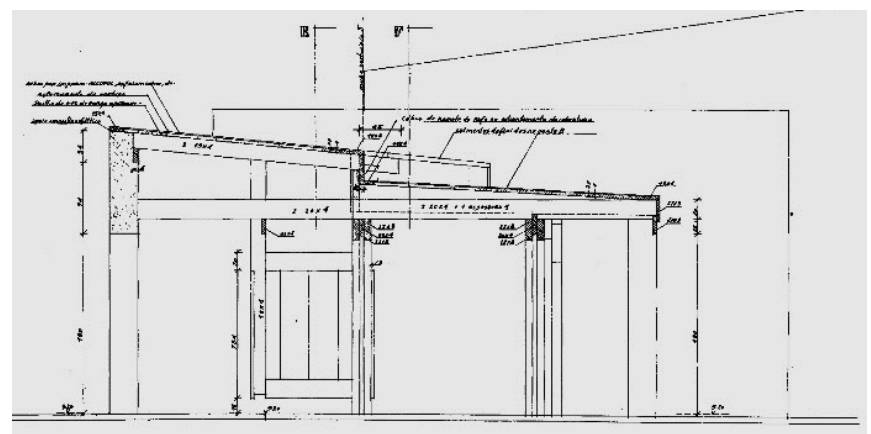

Figure 9 - Ocean Swimming Pool, A. Siza, cross section showing wooden structure and copper covering,1965. (Arquivo Câmara Municipal de Matosinhos)

\section{OCEAN SWIMMING POOLS. TOWARDS A MODERN CONSTRUCTION SITE}

The large amount of documentation available about the Ocean Swimming Pool (written, graphic and photographical) and oral sources (interviews to Arch. Alvaro Siza and to Eng. António Ferrão, son and former collaborator of Eng. Bernardo Ferrão who was the Engineer and contractor), made it possible, even over half a century later, to re-establish the history of a building site from the 1960s-1970s.

Hence, we can reconstruct the building site from the documents kept in the archives of Matosinhos Municipal Council (drawings, epoch photographs, project descriptions, budget estimates, chronograms, 
etc.), and in the Archives of the Faculty of Architecture of the University of Porto, though a report compiled, during his internship period, by a student of Architecture at the Porto School of Fine Arts. This report relates in particular to the third phase, which involved the extension of the buildings (Mota 1972).

\subsection{Building actors}

The construction of the Ocean Swimming Pool was programmed in four phases: in the first and second phases (1960-1966), the contractor was a small local firm, Ribeiro da Silva, Lda. (later purchased by a larger company, Mota Engil, Lda.), owned by the engineer Bernardo Ferrão (1913-1982), who designed all of the building's structures and infrastructures; the third and fourth phases (1965-73) were the work of the firm Enobra SARL (Mota 1972), including a project that involved the creation of a restaurant over the rocks, which was never built.

In all of the phases, the engineer was Bernardo Ferrão, who provided us with several important contributions to Construction History: on the one hand, through his experimental projects and built works (the Leça Movable Bridge, the Ribeira Tunnel, the retaining walls of the Douro riverside district, etc.), he was one of the first engineers in Portugal to use pre- and post-cast concrete (Oliveira 1983); on the other hand, as a prolific writer and editor, collecting information relating to the technical state of art (e.g. Retaining walls and masonry coatings - Ferrão 1945), Construction legislation and regulations (Ferrão 1944; 1962), Safety and accidents at work (Ferrão 1962), Contractors (Ferrão 1962) and the Accounting of public works (Ferrão 1963), among other subjects.

Thus, due to his great expertise, Bernardo Ferrão played an important role, working both as an engineer and a contractor in the construction of this building, which was one of the first in the country to make use almost exclusively of exposed concrete.

\subsection{Building materials and techniques}

This building is constructed with few materials and techniques: assembled copper coverings, reinforced concrete, stone and wooden structures and joinery. The wooden elements are assembled with brass screws and coated with a varnish that was traditionally used in shipbuilding, to create a washable and waterproof surface.

As far as concrete and stone are concerned, Ferrão had performed previous research and practical works specifically focused on retaining walls. The Swimming Pool's buildings are anchored at the lower level of the seaside avenue, In this way, all the east side walls are retaining walls (Figure 10) composed of two layers: i) an outer one made of reinforced exposed concrete and ii) an inner one in cyclopean concrete.

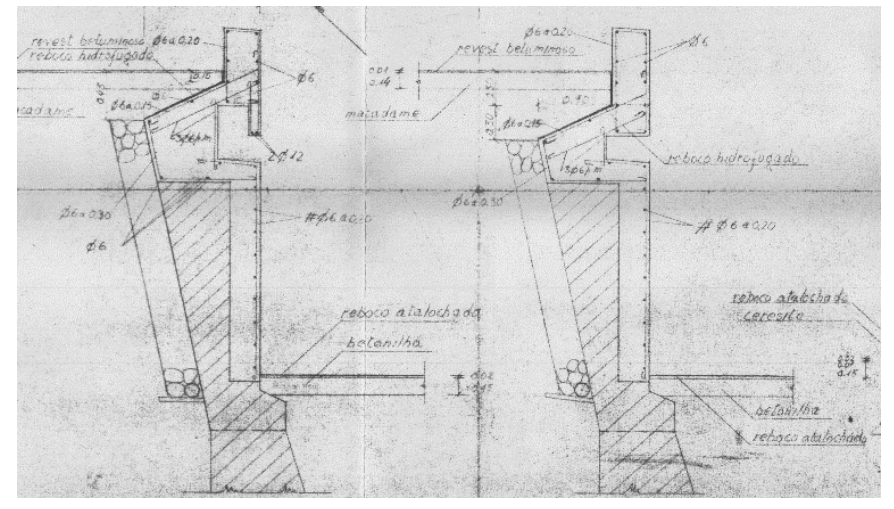

Figure 10- Ocean Swimming Pool, B. Ferrão, Retaining walls, 1970 (Arquivo Câmara Municipal de Matosinhos)

The back of the later has a layer of loose stones, with a draining pipe at the bottom, which works as a water draining curtain. This solution highlights the use of hybrid solutions of traditional construction solutions combined with modern ones that Siza was employing in his works during this period of his career.

As regards to the concrete used in the building site we have different composition: i) the cyclopean concrete walls were composed of stones, sourced from the site, filled with $300 \mathrm{~kg}$ cement plaster; ii) the foundation, the platforms pavements and the bar's triangular terrace is made out of $75 \%$ concrete of $250 \mathrm{~kg}$ cement; iii) the simple concrete walls are reinforced with $10 \mathrm{~kg}$ of rebar per $\mathrm{m} 3$ in the retaining walls and $15 \mathrm{~kg} / \mathrm{m} 3$ in the remaining walls; iv) the concrete roof slabs in the North and South roof gardens have $52 \mathrm{~kg} / \mathrm{m} 3$ of rebar and $130 \mathrm{~kg} / \mathrm{m} 3$ respectively; v) the North area, the slab also has a concrete beam (which extends to the retaining wall shown in figure 10) that is reinforced with $190 \mathrm{~kg} / \mathrm{m} 3$.

\subsection{Construction site, staff, chronogram}

The staff facilities were located at the northern end of the construction site: the supervisor's office $\left(6 \mathrm{~m}^{2}\right)$, the tool area $\left(15 \mathrm{~m}^{2}\right)$, a dormitory $\left(25 \mathrm{~m}^{2}\right)$; a kitchen with a small bathroom $\left(9 \mathrm{~m}^{2}\right)$.

The construction staff consisted of one civil engineer (the contract director), one builder (making the liaison between the contract director and the site foreman), one foreman, eight stonemasons, five carpenters, two builders and ten labourers.

The organisation and planning of the work were conducted by the technical office of the contractor's firm. The building site for the third phase was estimated to be in use for 210 days. The construction site chronogram was presented in the form of a GANTT bars type work plan (relating the works to be done with the weeks that were needed and the costs involved). The financial plan was based on a chart that included both the contractor's receipts and the contractor's payments. 


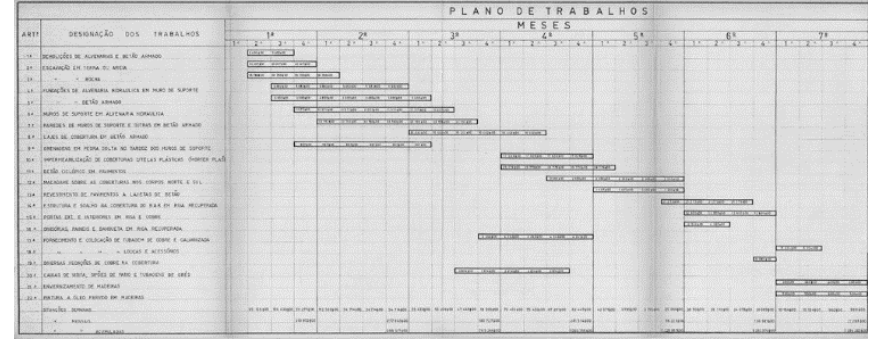

Figure 11- Ocean Swimming Pool, Construction site chronogram (Mota, 1972; Centro de Documentação da FAUP)

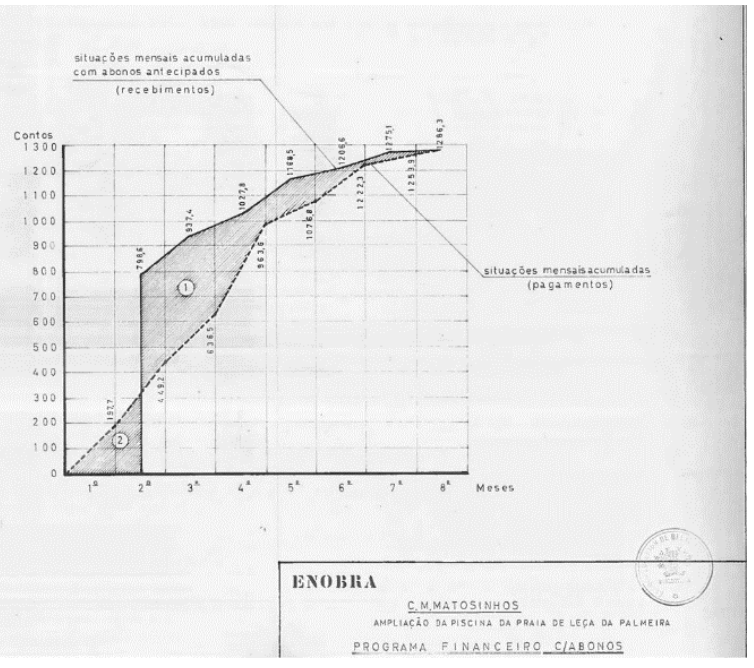

Figure 12- Ocean Swimming Pool, Construction site financial chart (Mota, 1972; Centro de Documentação da FAUP)

The building site included several areas for the manufacture and assembly of materials (steel reinforcement, formwork, masonry, among others). The area used for the assembly and cutting of steel was equipped with a folding table and manual cutting scissors. The amount of steel used in the third phase $(7000 \mathrm{~kg})$ did not require the use of more efficient electrical equipment. Similarly, the formwork area was very simple, with only one circular saw.

Moreover, the site had two concrete mixers that were used to produce a total volume of concrete of $800 \mathrm{~m}^{3}$ : one BH 400 from the NOE firm, with a production capacity of $12 \mathrm{~m}^{3} / \mathrm{h}$; and one that was used for finishing work, with a lower hourly output. To move the materials, there was a crane (type L 16, from the NOE firm) and a dumper truck (of the Thwaits Orion type, with a capacity of 800 litres).

\subsection{Excavations, foundations, landfills}

After the demolition of the previous retaining walls, a bulldozer was used to excavate the earth, sand and rock, with $1 / 3$ of what was left being rock, while the remaining $2 / 3$ consisted of earth. The rocks were broken up with the use of explosives, and were later reused for drainage purposes and for the hydraulic masonry walls and foundations.
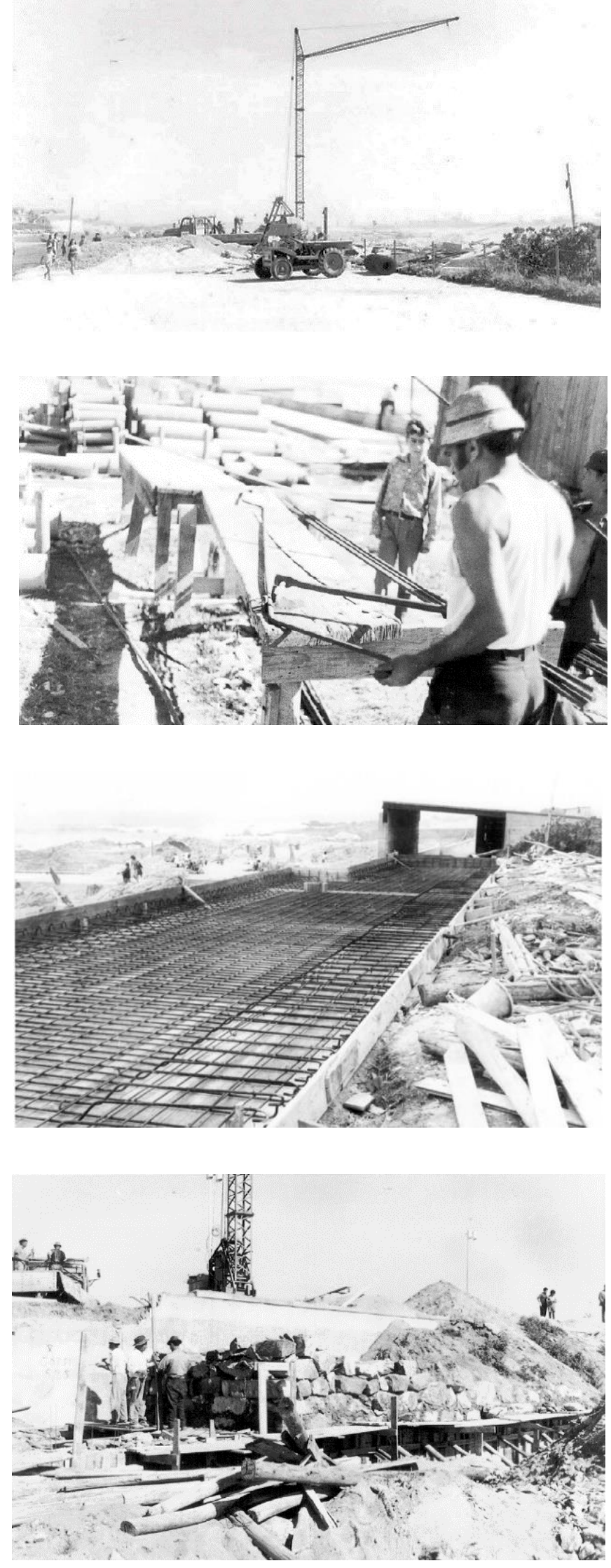

Figures 13-16 - Ocean Swimming Pool, building site, 1971-71 (Mota, 1972; Centro de Documentação da FAUP) 
The hydraulic masonry foundations were composed of rocks and mortar mixed with $300 \mathrm{~kg}$ of cement. The concrete foundations and their respective foundations were reinforced with steel and compacted by vibration.

Afterwards, the land was filled manually with $25 \mathrm{~cm}$ layers that were watered and beaten. The remaining debris was removed with a bulldozer and truck, and moved to a council refuse tip $(2 \mathrm{~km}$ from the site).

The drainage system on the back of the retaining walls was made with loose stone, manually arranged with a porous concrete pipe $(10 \mathrm{~cm}$ in diameter).

\subsection{Retaining walls and concrete walls}

The retaining walls at the northern and southern ends of the site were built in cyclopean concrete, with the stones being manually arranged, cleaned and watered. A plaster made of cement and sand was applied to the back of the walls, with 0.588 litres of 'Feb - proof' being used in the manufacture of each $50 \mathrm{~kg}$ of cement, making it water repellent and more compact.

The exposed concrete walls required a careful execution of the formwork in order to define the horizontal lines. The formwork was made of pinewood, which could be reused later thanks to its thickness $(4 \mathrm{~cm})$ and the application of oil. These walls are poorly reinforced, with a $5 \mathrm{~mm}$-thick mesh, consisting of a grid of $15 \times 15 \mathrm{~cm}$.

Stretchers were affixed to the side walls of the formwork. The shoring was made using $(15 \mathrm{~cm})$ pine posts and foundations.

All the expansion joints were made of Meyco rubber instead of copper because the former material offered better resistance to the vibrator during concreting. The slabs were also separated from the walls in order to provide an improved structural behaviour.

\subsection{Concrete slabs}

The roof slabs were built without any interruption (to avoid joints) and the concrete was mechanically vibrated, using a Wacker machine.

The slabs were waterproofed with prefabricated plastic-asphalt screens (Morter-Plas), using a polyethylene film cover on both sides and special catalytic asphalt layers. These were applied directly on top of the regularisation with fire-welded overlaps of $10 \mathrm{~cm}$. These screens reached all the way up to the roof plateau, with a double layer at the edges, where they were welded.

Moreover, a final protection was applied in the form of screed ( $1: 3$, cement and sand, with $3 \mathrm{~cm}$ and a spoon finish).

\subsection{Pavements}

All the exterior platforms and the southern ramp were made of cyclopean concrete, with $75 \%$ concrete (250kg of cement) and $25 \%$ splinter. A mortar made of cement and sand (1:3) was applied on the top.

The pavement in the north and south buildings received a water repellent and regulating screed with a plaster finish.

All the other exterior areas, the changing rooms and bathrooms have prefabricated slabs placed over a water repellent screed (4cm-thick), reinforced with a mesh and executed with white cement.

\subsection{Water supply, services and infrastructures}

The water supply network was made with galvanised pipes when it was built-in, and with copper pipes when it was exposed (in the showers and in the water supply for the urinals), while the taps and dowels were made of copper-plated brass.

The water used in the swimming pools is treated with three clarifying filters, made of mild steel sheet, circulating in iron pipes with the help of two groups of electric pumps, made of phosphorous copper. The swimming pools' water system is made of fibre cement pipes.

The rain and residual water is drained through glazed stoneware pipes, using patio syphons and visit boxes, floor drain boxes and connection boxes with brass drain grates. The bathrooms use syphon toilets, washbasins and urinals from Valadares, shower tubs and foot basins.

This building site is an expressive example of the dichotomy that was prevalent in the construction culture of this period, with traditional features (hidden retaining walls made of loose stone and concrete, wooden scaffolding, manual cutting scissors) being combined with the use of modern equipment and technology (crane, concrete mixer, rubber joints).

\section{CONCLUSIONS}

The three buildings presented in this paper demonstrate how the use of different construction methods and materials led to the development of a new architectural language. With the construction of the Ocean Swimming Pools, Siza affirms a construction culture transition that marked a turning point in his career and strongly influenced the subsequent production of other building actors. As mentioned earlier, this was the result of the evolution of the Portuguese construction culture and its accompanying debates in the 1950s and 1960s (together with the advances allowed by the industrialization of construction), leading to 
the affirmation of modern construction features, but also continuing to be linked to traditional building methods.

In the Swimming Pool of Quinta da Conceição and the Boa Nova Tea House Siza used traditional materials (timber and ceramic tiles) and modern techniques (reinforced concrete), combining vernacular and modern systems (tiled roofs placed over pitched concrete slabs and timberwork with a modern design). The Ocean Swimming Pool, however, affirms an abstract language made possible by the use of a modern form of construction: exposed concrete walls and slabs were shown with their rough natural appearance.

The use of exposed concrete ("beton brut" - Siza, 2019) in the Ocean Swimming Pool was also in line with the international debate, namely with the ethical and aesthetic brutalist approach of Reyner Banham appealing for a modernist urge to create simple and honest buildings based on three criteria: i) the clear exhibition of structure, ii) the valuation of materials 'as found' and iii) memorability as image (Banham 1955). Hence, this approach reacted against the humanist, neo-arts-and-crafts or decorative architectural trends of that time (Chadwick 2016) and defended an expressive, honest and meaningful use of industrial techniques and materials (such as concrete, steel frames and glass walls), which we can recognise in the Ocean Swimming Pool (Tostões 2016).

Although there are still relatively few sources available in Portugal relating to construction processes and sites (most contractors have not preserved their archives, so that information is often scarce and scattered in nature), this paper nonetheless provides contributions about the construction culture in the 1950s-1960s, in a period of transition between the continuity with traditional solutions and the affirmation of modern technologies and building sites. However, the present work is limited and shall be further expanded, crossing this building sites' brief analysis with other broader works (Vale, 2012; MascarenhasMateus \& Veiga, 2020, among others).

Finally, faced with a historiography that gives greater prominence to the conception and design (ideas and forms) in detriment to the actual constructed work (building site, materials, technologies and actors: architects, engineers, builders, workmen, etc.), it is important to go further beyond the history of architecture and architects and delve deeper into the "history of buildings", particularly in terms of their conception and construction processes.

\section{ACKNOWLEDGMENTS}

This work received the financial support of CEAU and Lab2PT. It was also co-financed by the European
Regional Development Fund (ERDF) through the COMPETE 2020 and Portuguese national funds from the FCT, under the the POCI-01-0145-FEDER007744 and POCI 010145 FEDER 007528 projects.

\section{REFERENCES}

Amaral, F. K. et al 1961. Arquitectura Popular em Portugal. Lisbon: SNA.

Banham, R. 1955. New Brutalism. Architectural Review, 688.

Chadwick, P. 2016. This Brutal World. London: Phaidon.

Fernandes, E. 2016. Os CODA da EBAP nos anos 40: das linguagens do Estado Novo à emergência de uma cons-ciência moderna. In Fátima Ferreira et al (ed.), A Con-quista Social do Território. Arquitetura e corporativismo no Estado Novo Português. Coimbra: Tenacitas.

Fernandes, E. \& Pereira, R. 2019. A metáfora do Grifo na obra de Januário Godinho: entre ecletismo, contextualismo e a retórica do Estado Novo. In Fátima Ferreira \& Eduardo Fernandes (eds.), Representações de Poder de Estado. Porto: LAB2PT/Circo de Ideias.

Ferrão, B. 1945. Perfis-Tipo e dimensionamento de suportes e revestimentos de alvenaria. Porto: Lopes da Silva.

Ferrão, B. 1947. Urbanização: legislação geral de uso corrente. Porto: Lopes da Silva.

Ferrão, B. 1962. Regulamento Geral das Edificações Urbanas. Porto: Livraria Lopes da Silva.

Ferrão, B. 1962. Empreiteiros de obras públicas. Porto: Livraria Lopes da Silva.

Ferrão, B. 1963. Contabilidade de obras públicas. Porto: Livraria Lopes da Silva.

Ferreira, T. \& Fernandes E. (in press). Alvaro Siza's Tectonic Shift in Leça da Palmeira: From Design to Conservation. In 16th International Docomomo Conference Tokyo Japan 2020+1. Inheritable Resilience: Sharing Values of Global Modernities. Tokyo: Docomomo.

Ganshirt, C. 2004. Piscina na praia de Leça da Palmeira. Lisbon: Blau.

Mascarenhas-Mateus, J. \& Veiga, I. 2020. Portugal Builds: Uma Plataforma digital para a História da Construção em Portugal nos séculos XIX e XX. In Estudos Históricos, vol 33, n 69, p.88-110.

Mota, R. 1972. Relatório de Estágio realizado sob a direção de A. Siza Vieira. Porto: ESBAP.

Oliveira, A. M. 1983. O Engenheiro D. Bernardo Ferrão. Boletim de Trabalhos Históricos. (XXIV): 109-111.

Siza, A. 1980. Piscina de Leça da Palmeira. In C. Campos Morais (ed.), 01 textos: Álvaro Siza, Porto: Civilização.

Siza, A., 2019. Interview with Magda Seifart and Pedro Baía. In Seifert, M \& Baia (eds), P. 2019. Porto Brutalista. Porto: Circo de Ideias.

Vale, C. P. 2012. Um alinhamento urbano na construção edificada do Porto - O Eixo da Boavista (1927-1999) Contributo para a História da Construção em Portugal no Século XX. Phd thesis. Porto: FAUP. 